Synthesis, part of a Special Feature on Practicing Panarchy: Assessing Legal Flexibility, Ecological Resilience, and Adaptive Governance in U.S. Regional Water Systems Experiencing Climate Change

\title{
Regime shifts and panarchies in regional scale social-ecological water systems
}

\author{
Lance Gunderson $^{1}$, Barbara A. Cosens ${ }^{2,3}$, Brian C. Chaffin ${ }^{4}$, Craig A. (Tony) Arnold ${ }^{5,6}$, Alexander K. Fremier ${ }^{7}$, Ahjond S. \\ Garmestani $^{8}, \underline{\text { Robin Kundis Craig }}^{9}, \underline{\text { Hannah Gosnell }}^{10}, \underline{\text { Hannah E. Birge }}^{11,12}$, Craig R. Allen $^{13}, \underline{\text { Melinda H. Benson }}^{14}, \underline{\text { Ryan }}^{\mathrm{R}}$. \\ Morrison $^{15}$, Mark C. Stone $^{14}$, Joseph A. Hamm $^{16}$, Kristine Nemec $^{17}$, Edella Schlager $^{18}$ and Dagmar Llewellyn $^{14}$
}

ABSTRACT. In this article we summarize histories of nonlinear, complex interactions among societal, legal, and ecosystem dynamics in six North American water basins, as they respond to changing climate. These case studies were chosen to explore the conditions for emergence of adaptive governance in heavily regulated and developed social-ecological systems nested within a hierarchical governmental system. We summarize resilience assessments conducted in each system to provide a synthesis and reference by the other articles in this special feature. We also present a general framework used to evaluate the interactions between society and ecosystem regimes and the governance regimes chosen to mediate those interactions. The case studies show different ways that adaptive governance may be triggered, facilitated, or constrained by ecological and/or legal processes. The resilience assessments indicate that complex interactions among the governance and ecosystem components of these systems can produce different trajectories, which include patterns of (a) development and stabilization, (b) cycles of crisis and recovery, which includes lurches in adaptation and learning, and (3) periods of innovation, novelty, and transformation. Exploration of cross scale (Panarchy) interactions among levels and sectors of government and society illustrate that they may constrain development trajectories, but may also provide stability during crisis or innovation at smaller scales; create crises, but may also facilitate recovery; and constrain system transformation, but may also provide windows of opportunity in which transformation, and the resources to accomplish it, may occur. The framework is the starting point for our exploration of how law might play a role in enhancing the capacity of social-ecological systems to adapt to climate change.

Key Words: adaptive governance; cross scale dynamics; social ecological system; transformation

\section{INTRODUCTION}

Humans have been altering ecosystems to manage water resources for millennia. Circa 4000 years ago, water in dry Mesopotamia was collected in reservoirs, channeled via levees, and moved around the landscape via canals and allocated through the code of Hammurabi (Cech 2003). Similar practices have been continued to date in most, if not all, regional scale freshwater social-ecological systems in the continental United States. These water systems have been modified and managed to meet a variety of societal goals including water supply, flood control, energy, agricultural and other economic production, as well as a growing environmental demand.

We use the phrase social-ecological systems to describe complex systems of people and the water (Dietz et al. 2003). Such systems consist of highly controlled ecosystems and a social system that mediates its interaction with ecosystems through environmental management and governance. Prior to intensive development, these North American water systems were dynamic ecosystems -riverine, riparian, wetland, and terrestrial - that supported complex biodiversity. During the 20th century, development of management systems accelerated, as dams and levees were constructed to constrain flood effects and provide water and energy for human activity. Channelization and other constructs allowed for the movement of water to meet social demands for agriculture, urban development, and economic growth. Land-use changes in the drainage basins have resulted in shifts in water quantity and quality, which in turn has altered ecosystem structures and functions. In short, development of water resources has led to ecosystems that are highly controlled and managed to meet specific social goals. Although river development has enhanced the economic wealth of society, it has done so at the expense of ecosystem functions. Management of these systems has largely centered on controlling and stabilizing key ecological processes to achieve these multiple social objectives. This optimization of certain services from our river systems has left them vulnerable to climate change, with very little room to adapt as patterns and quantities of precipitation and temperature change.

\footnotetext{
${ }^{1}$ Department of Environmental Sciences, Emory University, Atlanta, GA, USA, ${ }^{2}$ University of Idaho, Institute for Waters of the West, ${ }^{3}$ College of Law, Moscow, ID, USA, ${ }^{4}$ Department of Society \& Conservation, College of Forestry \& Conservation, University of Montana, Missoula, MT, USA, ${ }^{5}$ Brandeis School of Law, Department of Urban and Public Affairs and Center for Land Use \& Environmental Responsibility University of Louisville, Louisville, KY, USA, ${ }^{6}$ UCLA School of Law, Los Angeles, CA, USA, ${ }^{7}$ School of Environment, Washington State University, Pullman, WA, USA, ${ }^{8}$ U.S. Environmental Protection Agency, Cincinnati, OH, USA, ${ }^{9}$ S.J. Quinney College of Law, Global Change \& Sustainability Center, University of Utah, Salt Lake City, UT, USA, ${ }^{10}$ College of Earth, Ocean and Atmospheric Sciences, Oregon State University, Corvallis, OR, USA,

${ }^{11}$ Nebraska Cooperative Fish and Wildlife Research Unit, ${ }^{12}$ School of Natural Resources, University of Nebraska-Lincoln, Lincoln, NE, USA, ${ }^{13}$ U. S. Geological Survey, Nebraska Cooperative Fish and Wildlife Research Unit, School of Natural Resources, University of Nebraska, NE, USA, ${ }^{14}$ University of New Mexico, Albuquerque, NM, USA, ${ }^{15}$ Department of Civil and Environmental Engineering, Colorado State University, Fort Collins, CO, USA, ${ }^{16}$ School of Criminal Justice, Environmental Science and Policy Program, Michigan State University, East Lansing MI, USA, ${ }^{17}$ University of Northern Iowa Tallgrass Prairie Center, Cedar Falls, IA, USA, ${ }^{18}$ School of Government and Public Policy, The University of Arizona, Tucson, AZ, USA
} 
At this moment in time we observe growing interest in restoring a broad range of ecosystem services in our study basins. Restoration of ecosystem functions takes many forms, from recovery of endangered populations, restoration of vegetation and substrates in riparian and wetland zones, and ecosystem restoration. Given the onset of climate change a shift in focus is needed. The dynamic nature of ecosystems coupled with climate change renders restoration to historic conditions no longer possible. Furthermore, in a time of human domination of the planet, the viewpoint of our water-based ecosystems as separate and independent of society ignores reality, and thus at the same time, the loss of the breadth of ecosystem function due to optimization for 20th century services has placed these systems at risk. In contrast to the end points of optimization and restoration, we assert the need for reconciliation of ecosystem function with human dominance. Achieving reconciliation is not an ecological issue, a legal issue, an economic issue, nor a social issue. Rather it is a combination of all of these, which necessitates changes in both how we govern and manage these systems. It is also a time when water systems across North America are looking to re-engineer an aging water infrastructure with a view toward enhancing a broad range of social, economic, and ecological services. The uncertainty associated with dynamic systems, climate change, and the integration of multiple societal dependencies we suggest calls for new approaches, which has been described as adaptive governance (Dietz et al. 2003, Chaffin et al. 2014a).

Without integration of a deep understanding of both the legal landscape for water governance, its capacity for change, and the factors that lead to emergence of adaptive governance, we are unlikely to identify and implement the measures needed to prepare our water basins and the society that relies on them for governance capable of navigating the changes unfolding (Garmestani and Allen 2014). It is this integration that the Adaptive Water Governance (AWG) Project, the results of which are presented in this special feature, has sought to achieve.

\section{THIS ARTICLE}

We present an overview of seven basin assessments that form the backdrop for the efforts of the AWG Project. The six North American water basins that were chosen for basin assessment represent heavily regulated and developed social-ecological systems. The one Australian basin represents a free-flowing river system, yet one that is also within a federal system of regulation. We review the key components of the study basins and provide a brief summary of resilience assessments conducted in each system (Cosens et al. 2014, Cosens 2015). As such, the hope is to use this article for reference by the other articles in this special feature. The basin assessments show different ways that adaptive governance may be triggered, facilitated, or constrained by ecological and legal processes. The assessments indicate that as a result of interactions among the law, governance, and ecosystems, different trajectories (recovery, adaptation, transformation) characterize the histories of these social-ecological systems. We conclude with the role of governance trajectories and cross-scale interactions identified in the basins assessments in determining the capacity of the basins to navigate changing climate.

\section{CASE STUDIES: ASSESSING RESILIENCE IN SOCIAL- ECOLOGICAL WATER SYSTEMS}

In-depth assessments of six North American water basins (Fig. 1) and one basin in Australia have been published elsewhere (Arnold et al. 2014, Benson et al. 2014, Birge et al. 2014, Chaffin et al. 2014b, Cosens and Fremier 2014, Cosens et al. 2014, Gunderson et al. 2014, Cosens 2015). The basin teams have used a variety of approaches that build off earlier approaches to resilience assessment (Resilience Alliance 2010, Nemec et al. 2013), by adding assessment of governance and the role of law. In each assessment the question was posed as to the resilience of the basin's social-ecological system to changing climate.

Fig. 1. Location of riverine and wetland social-ecological systems in the United State used to study interaction of ecological resilience and adaptive governance. (Base map from public domain image, http://www.wikiwand.com/en/ List of rivers of the United States).

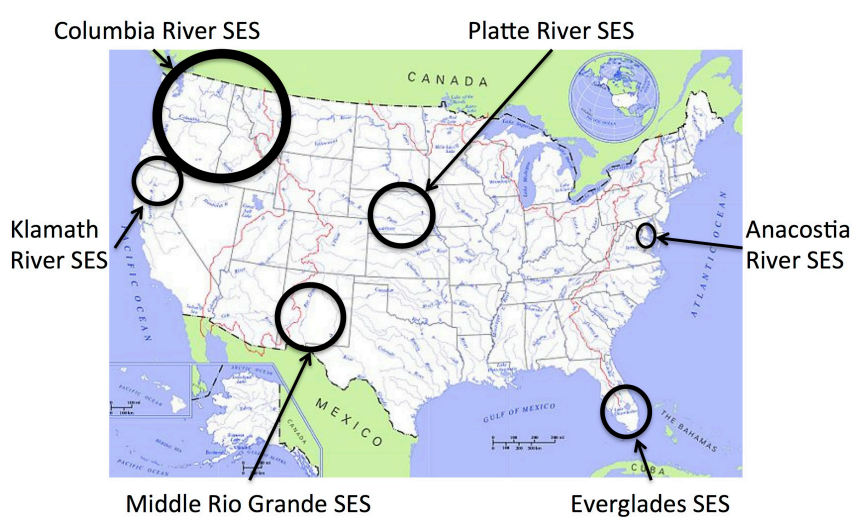

Broadly defined, climate is the long-term (decades to centuries) pattern of precipitation and temperature in a particular area (Intergovernmental Panel on Climate Change 2007). In regionalscale water systems, climatic patterns have been central to the design and management of such systems, and infrastructure and use allocation have been optimized on an assumption that the historic climate will persist. The climatic zones vary widely across the cases (Table 1). The Everglades has a subtropical savanna climate that is characterized by little seasonal change in temperature (rare freezing), with pronounced wet and dry seasons (Hela 1952), and the management system has evolved according to this annual cycle to control flooding during the wet season and supply water to agriculture, urban interests, and conservation areas during the dry season. Water basins in western North America experience substantial seasonal variability characterized by spring runoff from snowmelt (Mote et al. 2005), and water infrastructure and management is designed to even out the hydrologic cycle for flood control, hydropower, and irrigation (Cosens and Fremier 2014). These managed systems in the western U.S. are heavily reliant on natural storage of water in snowpack (Cosens et al. 2014). Yet a growing body of literature indicates that long-term changes in the hydrologic processes controlling these patterns in both the east and west are occurring, calling into question fundamental assumptions on which design 
Table 1. Characteristics of hydrologic basins in the United States used as case studies in assessing adaptive capacity, ecological resilience to rapid environmental change.

\begin{tabular}{|c|c|c|c|c|c|}
\hline Name & Basin Area $\left(\mathrm{km}^{2}\right)$ & $\begin{array}{l}\text { Average } \\
\text { Flow } \\
\left(\mathrm{m}^{3} / \mathrm{s}\right)\end{array}$ & $\begin{array}{l}\text { Maximum } \\
\text { Flow } \\
\left(\mathrm{m}^{3} / \mathrm{s}\right)\end{array}$ & $\begin{array}{l}\text { Climate } \\
\text { Zone(s) }\end{array}$ & Political Units \\
\hline Anacostia River & 456 & 1.5 & 51 & $\begin{array}{l}\text { Humid Subtropical } \\
\text { Climate }\end{array}$ & $\begin{array}{l}\text { United States } \\
\text { State of Maryland, Washington D.C. }\end{array}$ \\
\hline Columbia River & 668,000 & 7500 & 35,100 & $\begin{array}{l}\text { Semiarid Steppe, Alpine, } \\
\text { Marine West Coast }\end{array}$ & $\begin{array}{l}\text { United States, } \\
\text { States of Washington, Oregon, } \\
\text { Montana, Idaho, Wyoming, Nevada, } \\
\text { Utah } \\
\text { Canada, Province of British Columbia, }\end{array}$ \\
\hline Everglades Basin & 28,205 & 12 & 80 & $\begin{array}{l}\text { Humid Subtropical } \\
\text { Climate, } \\
\text { Tropical Wet/Dry }\end{array}$ & $\begin{array}{l}\text { United States } \\
\text { State of Florida }\end{array}$ \\
\hline Klamath River & 40,790 & 484 & 15,777 & $\begin{array}{l}\text { Semidesert, Dry alpine } \\
\text { Temperate rainforest }\end{array}$ & $\begin{array}{l}\text { United States, States of Oregon and } \\
\text { California }\end{array}$ \\
\hline $\begin{array}{l}\text { Middle Rio Grande } \\
\text { River }\end{array}$ & 72,000 & 41 & 707 & Semiarid Steppe & $\begin{array}{l}\text { United States, } \\
\text { States of Colorado and New Mexico }\end{array}$ \\
\hline Central Platte River & $219,916^{\dagger}$ & 199 & 4,530 & $\begin{array}{l}\text { Semi-arid Steppe, } \\
\text { Humid Continental }\end{array}$ & $\begin{array}{l}\text { United States, } \\
\text { States of Nebraska, Colorado, and } \\
\text { Wyoming }\end{array}$ \\
\hline
\end{tabular}

and management have been based (Milly et al. 2008). At the same time, the compromise of ecosystem functions through narrow purposed engineering has reduced the latitude within which these water systems may adapt without human intervention. The types of events associated with climate change including greater extremes in water supply will continue to test the resilience of the coupled social-ecological system to respond and adapt to these broad-scale changes. Understanding the dynamics of these complex social-ecological systems is urgent because climate change upsets the assumptions on which water infrastructure, allocation, and protection have been based.

The basin assessments illustrate that with the onset of water balance impacts from climate change some of the water supplies relied on in North America are close to irreversible thresholds. Once these thresholds are crossed, the services provided by altered ecosystems may threaten the adequacy of engineered infrastructure potentially impairing existing water-based economies. Basin assessment also made it clear that major investment in conservation, green infrastructure, ecological restoration, and reoperation of dams (Richter and Thomas 2007), will be necessary to increase the adaptability of water-based economies in the face of climate change. Achieving this will require governance that is capable of navigating change as well as itself evolving.

Assessment of adaptive governance facets (Table 2) illustrate an increasing attention to public input and participation in resource decision making. The recognition of treaty-based water and fishing rights of Native Americans in both the Klamath and Columbia rivers have led to increased participatory capacity from formerly marginalized populations. The emergent collaborative process among irrigators and Native American tribes in the Klamath basin illustrates both the change in power distribution and participatory capacity resulting from litigation and thus its role in opening a window to collaborative processes. This in turn has led to consideration of changes in basin management that may enhance general resilience in the face of climate change by focusing attention on the restoration of impaired ecosystem services.

\section{Anacostia River}

The Anacostia River (Table 3) runs through Washington D.C. then enters the Potomac River. The Anacostia has transitioned from a natural to an urban watershed in which restoration efforts will require intensive human intervention (Arnold et al. 2014). The watershed is home to over one million people. Changes in land use and other pollution sources have led to highly degraded waters. Implementation of the Clean Water Act and subsequent litigation has led to the emergence of local watershed organizations and adaptive efforts to restore aesthetic and recreational qualities in the watershed. The Anacostia governance structures are multiscalar across space, i.e., federalist, and are embedded in larger scale restoration programs (Chesapeake Bay). Thus, the federal and regional levels provide much of the knowledge and funding necessary for local capacity building and response. Increased resources for the emerging local organizations will be necessary to enhance adaptive capacity as the watershed responds to climate change (Arnold et al. 2014).

\section{Columbia River Basin}

Federal investment in the Columbia River (Table 4) located in the Pacific Northwest of the U.S. and Canada in the early 20th century led to development of major dam infrastructure to achieve the social objectives of flood control, navigation, irrigation, and hydropower (Cosens and Fremier 2014). Thus, regional investment by higher levels of government led to benefits for certain sectors of society within the basin and its nearby urban areas. Development also contributed to the precipitous decline in salmon populations that rely on the river and its tributaries for the freshwater portion of their life cycle. By the latter half of the century, the assertion of rights by Native American tribes led to 
Table 2. Relationships between components of the role of law in adaptive governance and panarchy theory, emphasizing how structures, capacities, and processes of government need to vary with phases of system development and cross-scale interactions.

\begin{tabular}{|c|c|c|c|c|}
\hline Component & Facet & $\begin{array}{l}\text { Development/Implementation } \\
\text { Phases }\end{array}$ & $\begin{array}{l}\text { Instability/ } \\
\text { Reorganization } \\
\text { Phases }\end{array}$ & $\begin{array}{l}\text { Panarchy/Cross Scale } \\
\text { Considerations }\end{array}$ \\
\hline \multirow[t]{6}{*}{ Structure } & Polycentricity & Multiple centers of authority & $\begin{array}{l}\text { Connections across loci } \\
\text { activate to respond to } \\
\text { ecological surprise }\end{array}$ & $\begin{array}{l}\text { Adaptive governance provides } \\
\text { bridge across multiple loci of } \\
\text { government }\end{array}$ \\
\hline & Redundancy & $\begin{array}{l}\text { Overlapping management and } \\
\text { multiple decision-making } \\
\text { functions }\end{array}$ & $\begin{array}{l}\text { Increases capacity for } \\
\text { unexpected ecological } \\
\text { dynamics }\end{array}$ & $\begin{array}{l}\text { Within and cross-scale functional } \\
\text { checks and balance }\end{array}$ \\
\hline & Complementarity & Multiple arenas for decisions & & \\
\hline & Subsidiarity & $\begin{array}{l}\text { Authority at scale of resource } \\
\text { issue }\end{array}$ & & $\begin{array}{l}\text { Resources/stability from larger } \\
\text { scales }\end{array}$ \\
\hline & Integration & & & $\begin{array}{l}\text { Local levels innovate } \\
\text { Across scales }\end{array}$ \\
\hline & Persistence & Formal networks established & $\begin{array}{l}\text { Informal networks emerge/ } \\
\text { disappear }\end{array}$ & $\begin{array}{l}\text { Cross-scale networks are available } \\
\text { to respond at the scale of the } \\
\text { problem rather than jurisdictional } \\
\text { scale }\end{array}$ \\
\hline \multirow[t]{2}{*}{ Capacity } & Adaptive & Adaptive management & $\begin{array}{l}\text { Adaptive planning, Adaptive } \\
\text { assessment }\end{array}$ & $\begin{array}{l}\text { Provide resources/capital for } \\
\text { responding to change }\end{array}$ \\
\hline & Participatory & $\begin{array}{l}\text { Determination of who } \\
\text { participates }\end{array}$ & Question of new participants & Rules for participation \\
\hline \multirow[t]{5}{*}{ Process } & Legitimacy & $\begin{array}{l}\text { Authority for exercise and } \\
\text { perception }\end{array}$ & $\begin{array}{l}\text { Provides opening for } \\
\text { reestablishment of or new } \\
\text { legitimacy }\end{array}$ & $\begin{array}{l}\text { Modes of decision making: science, } \\
\text { accountability, transparency }\end{array}$ \\
\hline & Procedural Justice & Maintains social stability & $\begin{array}{l}\text { Maintains trust and prevents } \\
\text { corruption when responding to } \\
\text { surprise }\end{array}$ & $\begin{array}{l}\text { Higher levels provide forums to } \\
\text { prevent local marginalization of } \\
\text { minority or disenfranchised groups }\end{array}$ \\
\hline & Problem Solving & $\begin{array}{l}\text { Allows accumulation of } \\
\text { knowledge about system } \\
\text { response }\end{array}$ & $\begin{array}{l}\text { Problem reframed the face of } \\
\text { uncertainty }\end{array}$ & $\begin{array}{l}\text { Scale matching: jurisdiction and } \\
\text { problem }\end{array}$ \\
\hline & Reflection/Learning & $\begin{array}{l}\text { Policy as hypothesis, single- } \\
\text { loop learning }\end{array}$ & $\begin{array}{l}\text { Multiple hypotheses, double- } \\
\text { loop learning }\end{array}$ & Memory and wisdom \\
\hline & $\begin{array}{l}\text { Balance between stability } \\
\text { and flexibility }\end{array}$ & $\begin{array}{l}\text { Resources from growth are } \\
\text { used to facilitate local capacity } \\
\text { building }\end{array}$ & $\begin{array}{l}\text { Increased flexibility at the scale } \\
\text { of the change }\end{array}$ & $\begin{array}{l}\text { Higher levels provide stability while } \\
\text { local levels innovate }\end{array}$ \\
\hline
\end{tabular}

their engagement in governance of fisheries. This major capacity building by formerly marginalized communities was made possible by the recognition of rights in federal court and funding for salmon recovery as a result of the U.S. Endangered Species Act. Although the economic goal of river development has been largely successful, its achievement through optimization has left the basin with limited room for adaptation and thus vulnerable to changing climate. In the Columbia River, the scale of governance extends to the international level. Current review of the treaty between the U.S. and Canada may be an opportunity for increasing management and infrastructure flexibility as well as reconciling certain ecosystem functions. (Cosens and Fremier 2014).

\section{Florida Everglades}

The Florida Everglades (Table 5) is a biologically rich, subtropical wetland that supplies water to about 8 million people, a multibillion dollar agriculture enterprise, and the conservation of biodiversity. Over the past century the system has successfully promoted economic and social development (Light et al. 1995). But like the Columbia River, this has come at an environmental cost measured in the listing of a dozen endangered species, and the imperiled Everglades National Park. The Everglades
Restoration Act of 2000 called for implementation of adaptive management to recover this vast ecosystem. The Everglades system has many of the attributes necessary for adaptive governance such as identified thresholds, the authority to experiment, e.g., adaptive management, and a diversity of institutions. Nevertheless, adaptive governance is hindered by overly prescribed planning and litigation, leaving the socialecological system of the Florida Everglades constrained in its capacity to adapt to climate change. In both the Columbia River Basin and the Florida Everglades, rigid management at higher levels and failure to balance stability of economic investment with flexibility to adjust management measures have formed impediments to implementation of a more flexible adaptive governance.

\section{Klamath River Basin}

The Klamath River Basin (Table 6) in southcentral Oregon and northern California has been the stage for a classic western water conflict between Native American tribes aligned with conservation organizations and commercial and recreational fishing interests, against irrigators served by a federal reclamation project and conservative local governments. The unique riverscape of the Klamath Basin supports irrigated agriculture in 
Table 3. Social-ecological regimes in the Anacostia River Basin. A small watershed in the humid urban-suburban areas of Washington, D.C. and Maryland, the Anacostia River basin has transitioned from biologically rich natural ecology prior to European settlement to three periods of ecosystem degradation due to agriculture and navigation, industrialization, and urbanization, to the present regime dominated by restoration and green infrastructure activities, yet still influenced by previous regimes' legacy effects and continued urbandevelopment pressures. The major drivers of regime shifts from presettlement to the present are the following: (1) societal treatment of the basin's waters, lands, vegetation, and wildlife as exploitable goods and services for short-term economic benefit (even in the current "green" regime in which improved water quality and restored lands are public goods and services); (2) shifts from weak to strong environmentalist values and activism; (3) changing ways that humans psychologically relate to the basin and its functions; (4) patterns of structural inequality, oppression, and discrimination, and movements to seek social and environmental justice; and (5) changes in governance institutions, including laws, to support and facilitate the dominant social values and policies of the time.

\begin{tabular}{|c|c|c|c|c|c|}
\hline Years & $\begin{array}{l}\text { Presettlement to } \\
\text { Mid-1600s }\end{array}$ & $\begin{array}{l}\text { Mid-1600s to } \\
\text { Mid-1800s }\end{array}$ & $\begin{array}{l}\text { Mid-1800s to Early } \\
1900 \text { s }\end{array}$ & $1900 \mathrm{~s}$ & Late 1900 s to Present \\
\hline Basin Regime & $\begin{array}{l}\text { Forests, Wetlands, } \\
\text { and Flows }\end{array}$ & $\begin{array}{l}\text { Agriculture and } \\
\text { Navigation }\end{array}$ & Industrialization & Urbanization & $\begin{array}{l}\text { Restoration and Green } \\
\text { Infrastructure }\end{array}$ \\
\hline Ecosystem States & $\begin{array}{l}\text { Climate change (to } \\
\text { warmer forest and } \\
\text { aquatic systems); } \\
\text { Ecological } \\
\text { productivity and } \\
\text { positive feedbacks } \\
\text { among forests, } \\
\text { wetlands, } \\
\text { biodiversity, and } \\
\text { clear-flowing } \\
\text { streams }\end{array}$ & $\begin{array}{l}\text { Deforestation; } \\
\text { Wetland draining and } \\
\text { filling; Farm soil } \\
\text { exhaustion; } \\
\text { Sedimentation; } \\
\text { Increasingly sluggish, } \\
\text { shallow, murky stream } \\
\text { flows; Re-engineered } \\
\text { river structure for } \\
\text { navigation }\end{array}$ & $\begin{array}{l}\text { Sewage flows to } \\
\text { waterways; } \\
\text { Water pollution } \\
\text { from toxic industrial } \\
\text { chemicals; Genesis } \\
\text { of extensive fish } \\
\text { cancers and } \\
\text { extirpation (legacy } \\
\text { effects in future } \\
\text { periods); }\end{array}$ & $\begin{array}{l}\text { Deforestation and } \\
\text { wetland loss; Altered } \\
\text { hydrology from } \\
\text { impervious land surfaces } \\
\text { and stormwater runoff; } \\
\text { Degraded water quality } \\
\text { (pathogens, nutrients, } \\
\text { sediments, and toxics); } \\
\text { Extirpated fish, wildlife, } \\
\text { submerged aquatic } \\
\text { vegetation }\end{array}$ & $\begin{array}{l}\text { Watershed restoration; } \\
\text { Green infrastructure for } \\
\text { stormwater management; } \\
\text { Reduced water pollution; Land } \\
\text { conservation; Reforestation; } \\
\text { Improvements in fish, wildlife, } \\
\text { and vegetation }\end{array}$ \\
\hline Social System States & $\begin{array}{l}\text { Native American } \\
\text { tribes created } \\
\text { villages, limited } \\
\text { farming, and } \\
\text { trading; } \\
\text { Exploration by } \\
\text { Europeans for } \\
\text { settlement }\end{array}$ & $\begin{array}{l}\text { Slavery; } \\
\text { Dominance of } \\
\text { agriculture and } \\
\text { commercial } \\
\text { navigation; } \\
\text { Poor farming } \\
\text { practices }\end{array}$ & $\begin{array}{l}\text { De jure racial } \\
\text { segregation; } \\
\text { Dominance of } \\
\text { industrial } \\
\text { development (but } \\
\text { start of significant } \\
\text { urbanization) }\end{array}$ & $\begin{array}{l}\text { De facto racial } \\
\text { segregation; } \\
\text { Gentrification of urban } \\
\text { neighborhoods; } \\
\text { Dominance of } \\
\text { urbanization and land } \\
\text { development }\end{array}$ & $\begin{array}{l}\text { Civil rights and environmental } \\
\text { movements; Grassroots } \\
\text { watershed activism; } \\
\text { Recreational and } \\
\text { environmental uses of waters } \\
\text { and lands; Urban growth } \\
\text { pressures }\end{array}$ \\
\hline Institutions & $\begin{array}{l}\text { Native American } \\
\text { norms and culture }\end{array}$ & $\begin{array}{l}\text { Land-clearance and } \\
\text { development laws; } \\
\text { Slavery }\end{array}$ & $\begin{array}{l}\text { Weak pollution } \\
\text { control laws; } \\
\text { Property and } \\
\text { contract rights (U.S. } \\
\text { Constitution); } \\
\text { De jure racial } \\
\text { segregation }\end{array}$ & $\begin{array}{l}\text { Private property rights; } \\
\text { Zoning; } \\
\text { Redevelopment policies } \\
\text { and laws; } \\
\text { Segregationist norms and } \\
\text { policies; Environmental } \\
\text { laws }\end{array}$ & $\begin{array}{l}\text { Clean Water Act regulation } \\
\text { and litigation; } \\
\text { Policies for stormwater control, } \\
\text { eco-restoration, and green } \\
\text { infrastructure; Multiscale } \\
\text { watershed partnerships; Civil } \\
\text { rights and participatory } \\
\text { governance }\end{array}$ \\
\hline
\end{tabular}

an arid upper basin of seasonally expanding, snow-fed lakes, rivers, and marshes, and a mountainous, forested lower basin that provides significant salmon spawning habitat. Current economies of the upper basin are reliant on continued irrigation water from the Klamath River, and Native American tribes in both the upper and lower basins are determined to maintain viable populations of culturally significant endangered and threatened fish species. Around the Oregon/California border, a natural constriction in the river provided the ideal sites for development of four hydroelectric dams in the mid-20th century, blocking fish passage to the upper basin, and significantly altering water quality in downstream reaches of the river. Although conflict over water and fish management in the Klamath Basin reached a stage of public protest in 2001, the continued role of law, in particular the Endangered Species Act and the assertion of Native American reserved water rights, ultimately served as the catalyst for emergence of collaborative processes and local adaptive solutions. These solutions are precarious if not formally institutionalized, and currently await federal approval and leadership. (Chaffin et al. 2014b).

\section{Middle Rio Grande Watershed}

The Middle Rio Grande (Table 7) in central New Mexico is defined as the portion of the river that runs from Cochiti Dam near Santa Fe to Elephant Butte Reservoir south of Albuquerque. Native American Pueblos, communities that date to Spanish settlement, and Anglo-Americans hold irrigation water rights. The river is regulated to provide water downstream to both Texas and Mexico. Management has been modified to protect endangered aquatic species. The system is very close to a threshold because of a combination of the following: overallocation of water pursuant to the prior appropriation doctrine; lax management including lack of definition and enforcement of water rights; urban development of groundwater hydrologically connected to the river despite an absence of consideration of groundwater lag times in conjunctive management; separation of the river from the floodplain; and extended drought due to climate change that is not only reducing water supply but altering the upland forest ecosystem and fire regime. Rigid political adherence and economic dependency on the existing development places the watershed's society in a vulnerable position. Transition without 
Table 4. Assessing system resilience and ecosystem services in the Columbia River Basin. Situated in the Pacific Northwest of the United States and Canada, the Columbia River Basin has undergone two major transformations in recorded history as a result of social-ecological interaction and is on the cusp of a third as shown in the table below. The two transformations during the 19th and 20th centuries led to increasing optimization of key services through engineered development of the river system, which in turn led to substantial increases in wealth and well-being among the European settlers and their descendants in the region. Corresponding to this optimization and increase in human capital, is a general reduction in natural capital across the broad array of ecosystem services present prior to European settlement. This in turn both reduced the latitude for adaptation (one component of resilience) and hardened dependence on historic amount and timing of water supply, leaving the basin vulnerable to climate change. The third transition which began with a growing recognition of environmental values and the rising voices of formerly marginalized Native American tribes and First Nations, has not yet transformed the social-ecological system in the basin, but has the potential for reconciliation of the development needs of modern society with ecosystem function through integrated modernization of both the engineered system and its governance. The table focuses on the U.S. portion of the basin except where international cooperation on river development is relevant. Eighty-five percent of the basin is in the United States.

\begin{tabular}{|c|c|c|c|c|}
\hline Years & $<$ mid-1800s & mid-1800s-1920's & $1920 \mathrm{~s}-1970 \mathrm{~s}$ & 1970s-present \\
\hline Era & Pre-European Contact & European Settlement & River Development & Environmental Justice \\
\hline $\begin{array}{l}\text { Ecosystem State } \\
\text { Changes }\end{array}$ & $\begin{array}{l}\text { Snowpack dominated } \\
\text { runoff high seasonal } \\
\text { variability; } \\
\sim 2 \text { million year } \\
\text { evolution of } \\
\text { anadromous fish runs }\end{array}$ & $\begin{array}{l}\text { Agricultural development; } \\
\text { timber harvest; railroad; } \\
\text { extinction of certain } \\
\text { predators; commercial } \\
\text { salmon harvest; first } \\
\text { hatchery; inland shipping } \\
\text { ports; locks for navigation }\end{array}$ & $\begin{array}{l}\text { Federal and international dam } \\
\text { development for hydropower, flood } \\
\text { control, irrigation, and navigation } \\
\text { alters the hydrograph, blocks } 37 \% \text { of } \\
\text { the basin's spawning grounds, } \\
\text { salmon populations plummet. Over } \\
200 \text { hatcheries. Effort to reduce } \\
\text { erosion from agricultural lands }\end{array}$ & $\begin{array}{l}\text { Investment in habitat restoration, } \\
\text { particularly on tributaries } \\
\text { Adjustment of dam operation to spil } \\
\text { during smolt migration } \\
\text { Variable improvement in salmon } \\
\text { runs. Increasing upland and former } \\
\text { floodplain development reducing } \\
\text { connectivity }\end{array}$ \\
\hline $\begin{array}{l}\text { Governance Shifts } \\
\text { and } \\
\text { Role of Law }\end{array}$ & $\begin{array}{l}\sim 10,000 \text { year indigenous } \\
\text { salmon fishery } \\
\text { Self-organization } \\
\text { around intertribal trade; } \\
\text { provision of fish to the } \\
\text { infirm; assurance that } \\
\text { some fish pass fishing } \\
\text { grounds }\end{array}$ & $\begin{array}{l}\text { Federal and private eastern } \\
\text { control on development. } \\
\text { States enter union, tribal } \\
\text { government depends on } \\
\text { federal law. New federal } \\
\text { law and policy leads to } \\
\text { active land management } \\
\text { and federal ownership will } \\
\text { remain between } 29 \% \text { and } \\
62 \% \text { for each state in the }\end{array}$ & $\begin{array}{l}\text { Federal dam building as part of the } \\
\text { New Deal increasing wealth and } \\
\text { stability. Capacity building of local } \\
\text { and state government. Treaty with } \\
\text { Canada to develop dams leads to } \\
\text { integration of electric grid and } \\
\text { emergence of an economic region } \\
\text { that contributes to WWII effort }\end{array}$ & $\begin{array}{l}\text { Tribal activism and use of federal } \\
\text { courts to establish treaty fishing } \\
\text { rights leads to capacity building and } \\
\text { increasing comanagement of the } \\
\text { fishery. Rise of the environmental } \\
\text { movement and major federal } \\
\text { environmental statutes. Listing of } 13 \\
\text { salmon and steelhead runs and } 2 \\
\text { resident fish species }\end{array}$ \\
\hline
\end{tabular}

Cross Scale Influences

Small to Large Salmon runs linked to hydrology. Fishery and intertribal trade tuned to salmon runs

Large to Small Floods, earthquake, and Federal funding, policy for volcanic activity, ENSO, western development, and shape landscape, water Indian policy dominates at supply, and connectivity the local level influence the evolution of salmon populations.
Local battles over private vs. public hydropower development scale up to national level

Federal funding and engineering essential to recovery from the Great Depression, and leads to emerging local capacity
Both the American Indian and the environmental movement begin as grass roots efforts

Availability of a federal forum to litigate tribal rights and willingness of Congress to pass environmental legislation at the federal level economic dislocation will require local leadership and capacity building as well as federal investment to restore some of the watershed's ecologic capacity to adapt and to reduce the degree of water dependency (Benson et al. 2014).

\section{Platte River Basin}

The water laws, policies, and infrastructure of the central Platte River Basin (Table 8) in south-central Nebraska have evolved during post-European settlement to optimize the needs of irrigation and flood control. Development has come at a high ecological cost to the system including aquatic and riverine habitat degradation and the listing of several endangered species. Listing has triggered responses to ecological degradation that include a tristate and federal collaborative Platte River Recovery and Implementation Program with the capacity to coordinate an adaptive approach to system-wide ecological restoration. The Platte River Recovery Program is a first step toward applying an adaptive management approach to restoration at the socialecological system scale (Birge et al. 2014).

\section{Lake Eyre and Great Artesian Basins, Australia}

The assessment of the Lake Eyre Basin and its connections to the Great Artesian Basin in Australia provided an opportunity to apply the results of the initial phase of the AWG Project and was used to test the legal guidelines presented in this special feature (Cosens et al. 2017). The internally draining Lake Eyre Basin covers 1.14 million $\mathrm{km}^{2}$ or roughly $15 \%$ of Australia, including much of Australia's outback. The basin encompasses parts of New South Wales, Queensland, and the Northern Territory, and its terminal lake, Lake Eyre, or Kati Thanda, as it is known to the 
Table 5. Resilience assessment of historical changes in the Florida Everglades. Situated in the southern portion of the Florida peninsula, the social-ecological system of the Everglades has undergone a series of transformations during the 20th century as indicated in the table below. Each transformation reflects a shift in the ecological components, social components, and/or governance regimes. At least five management regimes (Light et al. 1995) have been described, all of which were triggered by unforeseen environmental events or variation in hydrologic processes. Moreover, the transition among these different social-ecological configurations can be generally related to an erosion of system resilience. Such resilience is often linked to changes in slowly changing variables, either in the form of the loss of natural capital or increased vulnerability due to increasing forms of human capital.

\begin{tabular}{|c|c|c|c|c|c|}
\hline Years & $<1900$ & $1900-1947$ & 1947-1971 & 1971-1987 & 1988-Present \\
\hline $\begin{array}{l}\text { Regime } \\
\text { Description }\end{array}$ & Predrainage & Drainage & Flood Control & Water Supply & Ecosystem Restoration \\
\hline $\begin{array}{l}\text { Ecosystem State } \\
\text { Changes }\end{array}$ & $\begin{array}{l}\sim 6000 \text { year dynamic } \\
\text { wetland mosaic }\end{array}$ & $\begin{array}{l}\text { Sawgrass marsh } \\
\text { converted to } \\
\text { agriculture }\end{array}$ & Decline in biodiversity & $\begin{array}{l}\text { Nutrient induced } \\
\text { vegetation change }\end{array}$ & $\begin{array}{l}\text { Attempts to recover } \\
\text { ecosystem functions }\end{array}$ \\
\hline Governance Shifts & $\begin{array}{l}\text { Federal Swamp Act } \\
\text { of } 1850 \text { transferred } \\
\text { wetlands to the state } \\
\text { of Florida to drain } \\
\text { Everglades for } \\
\text { agriculture }\end{array}$ & $\begin{array}{l}\text { Drainage districts } \\
\text { forms }\end{array}$ & $\begin{array}{l}\text { Federal state flood } \\
\text { control district }\end{array}$ & $\begin{array}{l}\text { Water supply concerns } \\
\text { added to flood control }\end{array}$ & $\begin{array}{l}\text { Ecosystem restoration, } \\
\text { more litigation }\end{array}$ \\
\hline \multicolumn{6}{|l|}{$\begin{array}{l}\text { Cross-scale } \\
\text { Influences }\end{array}$} \\
\hline Small to Large & $\begin{array}{l}\text { Wetland ecology } \\
\text { linked to regional } \\
\text { hydrology }\end{array}$ & $\begin{array}{l}\text { Canal/levee } \\
\text { construction }\end{array}$ & $\begin{array}{l}\text { Balkanization of } \\
\text { hydrology, } \\
\text { Local drainage }\end{array}$ & $\begin{array}{l}\text { Drainage constrained, } \\
\text { spread of invasive species, } \\
\text { and nutrient-adapted } \\
\text { vegetation, }\end{array}$ & $\begin{array}{l}\text { All variables listed in } \\
\text { previous regimes, plus new } \\
\text { stakeholders and increased } \\
\text { litigation }\end{array}$ \\
\hline Large to Small & $\begin{array}{l}\text { Sea level rise, } \\
\text { cyclones, } \\
\text { ENSO variation }\end{array}$ & $\begin{array}{l}\text { Federal resources } \\
\text { input began }\end{array}$ & Flood events, & Droughts & $\begin{array}{l}\text { Federal, state, and local } \\
\text { support for ecosystem } \\
\text { restoration }\end{array}$ \\
\hline Slow variables & $\begin{array}{l}\text { Biodiversity, } \\
\text { speciation, } \\
\text { Soil accretion } \\
\text { Sea level }\end{array}$ & $\begin{array}{l}\text { Human population } \\
\text { increased }\end{array}$ & $\begin{array}{l}\text { Land use designation } \\
\text { (agriculture, } \\
\text { conservation, } \\
\text { water storage). } \\
\text { Everglades as } \\
\text { International Icon }\end{array}$ & $\begin{array}{l}\text { Soil nutrient } \\
\text { concentrations }\end{array}$ & $\begin{array}{l}\text { All variables listed in } \\
\text { previous regimes }\end{array}$ \\
\hline
\end{tabular}

traditional owners of the land, the Arabana (or Arabunna or Urabunna) people, is in South Australia. The Lake Eyre Basin is sparsely populated and its highly variable rivers remain freeflowing.

The primary legacy effect of the human development of water in the basin is the thousands of bores developed in the late $1800 \mathrm{~s}$ and early 1900s in the Great Artesian Basin (the groundwater basin extending under and beyond the Lake Eyre surface water basin) for pastoral use. Efforts are underway to cap and control bore flows as pressures within the Great Artesian Basin aquifers decline, but many remain free-flowing. The impact of colonization and the lack of recognition of Native title to land and waters until recent years has had a lasting impact on the capacity of Aboriginal communities in the basin to participate in water management. Recent studies indicate that climate change may reduce precipitation and increase temperatures in the southern portion of the basin, while the northern portion of the basin, which supplies the runoff from monsoonal rains to the basin, may experience increased precipitation and greater extremes. The Lake Eyre and Great Artesian basins are currently managed separately. Lake Eyre Basin is subject to an intergovernmental agreement between the Commonwealth, the states of Queensland and South Australia, and the Northern Territory, which only addresses the avoidance of cross-border impacts and, despite policy statements aspiring to a whole-of- basin management approach, does not provide the framework or authority for basin-wide management; rather, intra-state water management is the subject of state law.

Cosens (2015) identified a series of governance issues facing the basin. Building avenues for participation by Aboriginal communities remains a challenge, as does increased local participation in state and federal planning and management activities. Governance should be more consistent in applying and enforcement of bore capping efforts. Conjunctive management of surface and groundwater is an ongoing challenge.

Another gap is the lack of a binding dispute resolution mechanism for disputes among the states concerning water development. Such challenges create a fragile and vulnerable system in the face of climate change (Cosens 2015).

\section{ADAPTIVE GOVERNANCE AND PANARCHIES OF CHANGE}

The ways in which we utilize, manage, and govern natural resources must be connected to ecological theory if society is to manage change in these systems. Just as the development of ecological resilience theory in the 1970 s led to resource management approaches such as adaptive management (Holling 1978), the development of Panarchy theory (Gunderson and Holling 2002) has been a useful framework for the development 
Table 6. Resilience assessment of the Klamath River Basin social-ecological system (SES). The Klamath River Basin contains a unique river system originating in the arid interior of southcentral Oregon west of the Cascade Range and flowing through the mountainous rain shadow of northern California toward the Pacific Ocean. During the course of human history in the basin, the overall resilience of the basin to regime shift has oscillated according to interactions between forces of environmental governance and ecological responses, originating both from within and beyond the basin. To better understand the contemporary resilience of the Klamath River Basin to disturbance and sudden change, it is helpful to investigate and map historic patterns of system change through the adaptive cycle metaphor of SES dynamics. Below we employ the phases of the adaptive cycle to describe the dynamics of the most recent iteration of this cycle in the Klamath Basin. Although we recognize that several scales of nested cycles likely contribute to and further describe the dynamics portrayed here, the basin scale is a helpful unit of analysis to feedback to both social and ecological aspects of governance.

\begin{tabular}{|c|c|c|c|c|}
\hline $\begin{array}{l}\text { Phase of the Adaptive } \\
\text { Cycle }\end{array}$ & Exploitation (r) & Conservation (K) & Release $(\Omega)$ & Reorganization $(\alpha)$ \\
\hline Years & $<1960$ s & $1960 s-2001$ & 2001-2004 & 2004-present \\
\hline $\begin{array}{l}\text { Ecosystem } \\
\text { Modifications/ Dynamics }\end{array}$ & $\begin{array}{l}\text { Resource allocation: drainage } \\
\text { and irrigation of upper basin } \\
\text { wetlands; fragmentation of } \\
\text { Klamath River for } \\
\text { hydropower; blocked river } \\
\text { passage for migrating salmon; } \\
\text { increased salmon harvest }\end{array}$ & $\begin{array}{l}\text { Slow variables persist: } \\
\text { persistent drought; } \\
\text { decreased river flow; } \\
\text { degradation of water } \\
\text { quality; increase in toxic } \\
\text { algal blooms; decreased } \\
\text { habitat for aquatic and avian } \\
\text { species }\end{array}$ & $\begin{array}{l}\text { Collapse: fall-run Chinook } \\
\text { salmon mortality event } \\
\text { (2002); breeding populations } \\
\text { of sucker fish drop below } \\
\text { sustainable levels; anoxic } \\
\text { conditions in river } \\
\text { reservoirs; viable species } \\
\text { habitat loss; avian mortality } \\
\text { events }\end{array}$ & $\begin{array}{l}\text { Tenuous regime stabilization: } \\
\text { salmon and sucker species } \\
\text { remain, although viability } \\
\text { questionable; improvements in } \\
\text { tributary water quality; some } \\
\text { habitat restoration }\end{array}$ \\
\hline $\begin{array}{l}\text { Social Dynamics } \\
\text { Influencing Governance } \\
\text { Shifts }\end{array}$ & $\begin{array}{l}\text { Marginalization: Euro- } \\
\text { American land acquisition; } \\
\text { privatization of property; } \\
\text { removal of Native Americans } \\
\text { to reservations }\end{array}$ & $\begin{array}{l}\text { Slow variables persist: } \\
\text { aggregation of small farms } \\
\text { to agribusinesses; racial } \\
\text { tensions between Euro- and } \\
\text { Native Americans; slow } \\
\text { gains in Native American } \\
\text { sovereignty over land, water, } \\
\text { and species; creation of } \\
\text { fragmented cultures of } \\
\text { environmental management }\end{array}$ & $\begin{array}{l}\text { Crisis: dominant } \\
\text { environmental laws collide } \\
\text { (ESA, reclamation policy, } \\
\text { federal-tribal trust } \\
\text { responsibility); shutoff of } \\
\text { irrigation water to the } \\
\text { Klamath Reclamation } \\
\text { Project; economic loss; } \\
\text { antigovernment protest; } \\
\text { racial violence }\end{array}$ & $\begin{array}{l}\text { Potential for transformation: } \\
\text { venues emerge for productive } \\
\text { conflict resolution; personal } \\
\text { transformation of basin } \\
\text { leadership; federal, state, and } \\
\text { NGO investment in } \\
\text { negotiation venues; } \\
\text { mobilization of adaptive } \\
\text { capacity }\end{array}$ \\
\hline Controlling Variables & $\begin{array}{l}\text { Fast: social and ecological } \\
\text { marginalization }\end{array}$ & $\begin{array}{l}\text { Slow: climate change; } \\
\text { resource overuse; capitalism }\end{array}$ & $\begin{array}{l}\text { Fast: ecological collapse; } \\
\text { social crisis }\end{array}$ & $\begin{array}{l}\text { Fast and slow: new } \\
\text { configurations of adaptive } \\
\text { capacity }\end{array}$ \\
\hline
\end{tabular}

and understanding of adaptive governance (Chaffin et al. 2014a, Chaffin and Gunderson 2016). Panarchy theory proposes that systems, defined at specific spatial and temporal scales, exhibit common patterns of change or trajectories over time.

Panarchy theory decomposes system dynamics into those that are scale dependent (such as the system trajectories) and cross scale interactions (Gunderson and Holling 2002). Types of interactions occur from larger scale systems (top down) and processes that scale up from smaller scales (bottom up). Such interactions do not occur continuously, but are associated with different phases of system change. Bottom-up ecological processes can result in instabilities as a result of cascading phenomena. Forest fires, pest outbreaks, and political revolutions and epidemics are all examples of such processes and are called revolts (Gunderson and Holling 2002). Top-down instabilities can occur as well; ecological examples include tropical cyclones in the Everglades, ENSO in western U.S. water basins; social examples include political elections, and implementation of a major change in regulation such as that resulting from federal listing of an endangered aquatic species in the basin. Another key cross scale interaction occurs when broader scale processes are critical during a system reorganization phase. One example is how shifts in functional forms of biodiversity that alter trophic relationships can result in regime shifts (Folke et al. 2004). The trajectory of ecological regime shifts occur after systems can depend critically on broad scale influences during reorganization.

Thus, a connection must be made between the system trajectories and the law related to system management and cross-scale interactions if social-ecological systems are to navigate change without major disruption. The following paragraphs discuss the identification of different trajectories within our basin studies and the role of cross scale interactions.

A common trajectory can be described as a growth and development path; infrastructure is built and operated to achieve particular societal goals (Holling and Meffe 1996). In the water case studies, these pathways involved the construction of dams, levees, canals to control and constrain water movement to meet social goals of flood control and water supply. During the periods of growth and development many formal governance structures were devised to oversee construction and implementation of infrastructure. Also, multiple authorities for resource allocation were specified. Much of the governmental aspect of governance needed during these periods focuses on coordination among redundant, overlapping management loci, multiple nodes of decision making and rules for participation by stakeholders. Among the case studies, the small and mighty rivers were tightly controlled and regulated during these eras of development. As a result, the social objectives of flood control and water diversion 
Table 7. Resilience assessment of historical changes in the Middle Rio Grande. New Mexico's Middle Rio Grande watershed includes the urban environments of Albuquerque, Santa Fe, as well as surrounding small towns, and rural agricultural communities. Dams and levees provided the necessary infrastructure for Anglo settlement, but resulted in loss of biodiversity. Pressures of urbanization, water supply constraints, and a history of a highly variable and unpredictable water availability are requiring increased adaptive capacity in the social system. The upper watershed forest system is undergoing regime change due to historic fire suppression followed by drought conditions. Long-term climate change projections indicate that the watershed will experience ongoing drought in the coming decades, with water shortfalls and extended dry intervals expected to become increasingly common.

\begin{tabular}{|c|c|c|c|c|}
\hline Years & $<1930$ s & $1930 s-1990 s$ & $1992-2010$ & 2010-Present \\
\hline Regime Description & Pre-Dams and Levees & Dams and Levees & Environmental Flows & Ecosystem Restoration \\
\hline $\begin{array}{l}\text { Ecosystem State } \\
\text { Changes }\end{array}$ & $\begin{array}{l}\text { Upper watershed frequent } \\
\text { low intensity fire; valley } \\
\text { floodplain braided, wide } \\
\text { channel }\end{array}$ & $\begin{array}{l}\text { Floodplain converted to } \\
\text { agriculture; } \\
\text { channelization of river } \\
\text { Fire suppression in upper } \\
\text { watershed }\end{array}$ & $\begin{array}{l}\text { Decline in biodiversity due to } \\
\text { channelization; riparian } \\
\text { cottonwoods stop } \\
\text { regenerating; high intensity } \\
\text { fire, bark beetle infestation, } \\
\text { and drought in upper } \\
\text { watershed }\end{array}$ & $\begin{array}{l}\text { Attempts to recover ecosystem } \\
\text { functions }\end{array}$ \\
\hline Governance Shifts & $\begin{array}{l}\text { Pueblo and Hispanic } \\
\text { communities; small scale } \\
\text { infrastructure; share } \\
\text { sharing }\end{array}$ & $\begin{array}{l}\text { Anglo settlement; Middle } \\
\text { Rio Grande Conservancy } \\
\text { District Formed; } \\
\text { prior appropriation doctrine }\end{array}$ & $\begin{array}{l}\text { Listing of endangered species } \\
\text { under the Endangered Species } \\
\text { Act; U.S. Fish and Wildlife } \\
\text { Service consulted over dam } \\
\text { operations }\end{array}$ & $\begin{array}{l}\text { Ecosystem restoration, more } \\
\text { litigation of implementation of } \\
\text { ESA }\end{array}$ \\
\hline \multicolumn{5}{|l|}{ Cross Scale Influences } \\
\hline Small to Large & $\begin{array}{l}\text { Upper watershed forest } \\
\text { and seasonal flooding }\end{array}$ & $\begin{array}{l}\text { Canal/levee } \\
\text { Construction; Anglo } \\
\text { settlement }\end{array}$ & $\begin{array}{l}\text { Channelization Upper } \\
\text { watershed forest supply }\end{array}$ & $\begin{array}{l}\text { All variables listed in previous } \\
\text { regimes, plus drought }\end{array}$ \\
\hline Large to Small & localized agreements & $\begin{array}{l}\text { State water allocation } \\
\text { regime }\end{array}$ & $\begin{array}{l}\text { Federal resources input began; } \\
\text { Collaborative program }\end{array}$ & $\begin{array}{l}\text { Litigation results in stagnation of } \\
\text { collaborative program }\end{array}$ \\
\hline Slow variables & Biodiversity & $\begin{array}{l}\text { Human population } \\
\text { increases }\end{array}$ & $\begin{array}{l}\text { Land use and water allocation } \\
\text { pressure due to continued } \\
\text { population growth and } \\
\text { drought }\end{array}$ & $\begin{array}{l}\text { All variables listed in previous } \\
\text { regimes }\end{array}$ \\
\hline
\end{tabular}

for human use were achieved. During these phases, governance becomes focused on efficiency and cost control, and economic components become dependent on continued growth. Development and growth in all of the North American case studies relied on resources and capacity building from the federal level and management that is at the same time redundant, overlapping, and contested among federal, state, and local levels. As water management systems develop over time, policies and actions have been largely successful in meeting social objectives. This is a period or time of formal structures of governance, or institutionalization in law and government (Chaffin and Gunderson 2016). But it is also a period in which the growth and stability of higher levels of government might have facilitated preparation and development of tools to navigate change. Among these are cross-scale and cross-sector networks, and the use of resources to build local capacity as well as to re-engineer local water infrastructure to provide space for adaptation.

In all of the case studies, as systems developed over time, their resilience decreased making these systems more vulnerable to external forces (Gunderson and Holling 2002). In the six North American case studies, these external shocks came in the form of high or low rainfall periods, storm events, or other natural disasters, as well as the imposition of new regulations or assertion of rights through litigation that threatened existing economies. Each of these events was viewed as a crisis or instability, which then led to reflexive activities that influence the future system trajectories (Holling and Gunderson 2002).
Following such periods of instabilities, the systems reorganized and started new phases of growth and development. It was during the period of reorganization that system resilience is tested, and the period in which a new regime (as described above) can come into being. Such new regimes are characterized by a different set of processes and structures. These periods are when adaptive governance may emerge through formal and informal networks of response to the disturbance provided the appropriate structure, capacity, and processes are, at best, in place to facilitate its emergence, and at a minimum, not creating barriers (Table 2). This is also the period in which cross-scale interactions are critical.

During phases of instability and reorganization, new connections across loci of governance emerge or are strengthened. Examples include the formation of National Academy of Science committees in the Columbia River, or the Klamath Basin. Such emergent groups tend to be epistemic, and focus on resolving uncertainties that contributed to the resource surprise, and what are possible responses and adaptation to the unforeseen system dynamics. Cross-scale interactions may facilitate these connections through the provision of resources including technical support from higher levels of government.

For example, in the Klamath River Basin, after a period of partial ecological collapse and social crisis in the basin, a handful of leaders from different resource use and management interests in the basin came together under a series of opportune venues that emerged across the basin. These venues, and the desire of basin 
Table 8. Resilience Assessment of Historical Changes in the Platte River Basin. Extending across portions of northeast Colorado, southeast Wyoming and central Nebraska, the social-ecological system of the Platte River Basin has undergone a series of transformations during the 19th and 20th century. Each transformation reflects a shift in the ecological components, social components and/or governance regimes. We describe three regimes, each of which were partially triggered by changes in system governance, with direct and indirect consequences for interactions among social-ecological components of the system.

\begin{tabular}{|c|c|c|c|}
\hline Years & $<1840$ & $1902-1997$ & 1997- Present \\
\hline Regime Description & Pre Intensive European Settlement & Electrification and Damming & Platte River Recovery Project (PRRIP) \\
\hline $\begin{array}{l}\text { Ecosystem State } \\
\text { Changes }\end{array}$ & $\begin{array}{l}\text { Braided river, sandbars, high } \\
\text { floodplain-river connectivity, } \\
\text { spring flooding }\end{array}$ & $\begin{array}{l}\text { Channelization of the river, loss of flood } \\
\text { driven sandbars and wetlands }\end{array}$ & $\begin{array}{l}\text { Attempts to recover ecosystem functions, } \\
\text { especially those surrounding basin's } \\
\text { endangered species, and required by the } \\
\text { Endangered Species Act (ESA) }\end{array}$ \\
\hline $\begin{array}{l}\text { U.S. Governance } \\
\text { Shifts }\end{array}$ & $\begin{array}{l}\text { Federal Government owns } \\
\text { majority of land and sells it } \\
\text { sparingly }\end{array}$ & $\begin{array}{l}\text { Homestead and Reclamation Act } \\
\text { encourages settlement of the basin and } \\
\text { "beneficial use" of water resources, } \\
\text { respectively }\end{array}$ & $\begin{array}{l}\text { PRRIP (agreement among CO, NE, and WY) } \\
\text { is approved by US Congress. Increased } \\
\text { litigation surrounding ESA }\end{array}$ \\
\hline \multicolumn{4}{|l|}{ Cross Scale Influences } \\
\hline Small to Large & $\begin{array}{l}\text { Riverine wetlands provide habitat, } \\
\text { nutrient cycling and flood } \\
\text { buffering }\end{array}$ & $\begin{array}{l}\text { Storage and hydroelectric project } \\
\text { construction }\end{array}$ & $\begin{array}{l}\text { All variables listed in previous regimes, plus } \\
\text { new stakeholders and litigation surrounding } \\
\text { ESA }\end{array}$ \\
\hline Large to Small & $\begin{array}{l}\text { Rockies snowpack drives spring } \\
\text { flooding }\end{array}$ & $\begin{array}{l}\text { Flood events are no longer absorbed by } \\
\text { floodplain }\end{array}$ & $\begin{array}{l}\text { Federal, State and local support for PRRIP, a } \\
\text { large scale adaptive management plan }\end{array}$ \\
\hline Slow variables & $\begin{array}{l}\text { Biodiversity, speciation, wetland } \\
\text { and sandbar maintenance, and } \\
\text { soil formation }\end{array}$ & $\begin{array}{l}\text { Increasing human populations. } \\
\text { Agriculture begins to dominate the basin's } \\
\text { landscape. Surface and ground water } \\
\text { depletion. }\end{array}$ & All variables listed in previous regimes/ \\
\hline
\end{tabular}

leaders to find a collective solution to the ongoing social and ecological problems plaguing the entire basin, helped to facilitate a series of discussions that led to trust-building, network formation, and negotiation over resource use and allocation, significant enough to inspire buy-in and investment from NGOs as well as state and federal governments. Within this coalition of leaders, epistemic networks were formed and venues were created for discussion, negotiation, and social learning around specific aspects of the Klamath conflict including endangered fish restoration, hydrologic and water use modeling, and legal conflict resolution (Chaffin 2014).

In addition, new forms of management or new forms of government may emerge separately or to institutionalize those that have informally arisen. One example is the creation of the South Florida Water Management District, following a severe drought in the Everglades (Light et al. 1995). Another example is the establishment of the Northwest Power and Conservation Council in the U.S. portion of the Columbia River, an interstate council authorized by Congress to engage with the public in regional electric power planning and enhancement of fish and wildlife within the basin.

Control and resources from larger scales may constrain subsequent system trajectories in ways that have been described as maladaptive or as a rigidity trap (Holling 2001). Thus, barriers to adaptive governance emergence during reorganization may occur when cross-scale interactions infuse resources to maintain the status quo rather than to facilitate innovation. This continuation of the growth cycle in the face of disturbance simply increases the vulnerability of the system to the next shock. At the other end of the spectrum, absence of a higher scale of government to provide resources for local innovation and reorganization following a disturbance may result in substantial social and economic dislocation.

Cases study regions, such as the Everglades social-ecological system, appear to be in a rigidity trap, and are quite resilient to change (Gunderson and Light 2006). Trapped systems have high institutional diversity (numerically and functionally) yet can only appear to change (for better or worse) following crises. Although polycentric, the Everglades governance system is hierarchical, rigid, and inflexible. Another indication is the inability to negotiate (or even discuss) many policy changes, much less attempt them. The result of large influxes of capital have sustained existing power relations in the system, leading to the current governance and management system being described as a rigidity trap (Gunderson et al. 2014). Another key characteristic of the systems perverse resilience is how novelty, experimentation, and uncertainty are confronted.

By using this framework to connect the understanding of complex system response in ecological systems to an understanding of the complex governance systems that mediate social-ecological system interaction, it becomes possible to chart a course more likely to assist society in the navigation of change. Moving from identification of the role of system trajectories and cross-scale interactions, i.e., panarchy, in the basins studied, to synthesis of the key lessons this framework and other theoretical constructs provide for understanding the barriers and opportunities for enhancing the adaptability of regulated water systems is the goal of this special feature.

\section{SUMMARY}

The six North American water basins that were chosen to investigate the interaction among ecosystems, legal systems, and 
adaptive governances all represent heavily regulated and developed social-ecological systems. Reviews of the historical development or trajectories of these systems reflect complex interactions among adaptive governance, ecosystem regimes, and the legal systems. The basin assessments show different ways that adaptive governance may be triggered, facilitated, or constrained by ecological and/or legal processes. The basin assessments indicated that complex interactions among the legal, governance, and ecosystem components of these systems can produce different trajectories, which include patterns of (a) development and stabilization, (b) cycles of crisis and recovery, which includes lurches in adaptation and learning, and (3) periods of innovation, novelty, and transformation.

Responses to this article can be read online at: http://www.ecologyandsociety.org/issues/responses. $\mathrm{php} / 8879$

\section{Acknowledgments:}

This work was developed under the Adaptive Water Governance Project, funded by the U.S. National Socio-Environmental Synthesis Center (SESYNC) under funding from the U.S. National Science Foundation, NSF DBI-1052875. The authors would like to thank Margaret Palmer and Jonathan Kramer of SESYNCfor their belief in and support of the project. We would also like to thank the all participants in the Adaptive Water Governance Team whose work is reflected in the articles in this special feature and without whom it would not have been possible. The Nebraska Cooperative Fish and Wildlife Research Unit is jointly supported by a cooperative agreement among the U.S. Geological Survey, the Nebraska Game and Parks Commission, the University of Nebraska, the U.S. Fish and Wildlife Service, and the Wildlife Management Institute.

\section{LITERATURE CITED}

Arnold, C. A., O. O. Green, D. Decaro, A. Chase, and J. G. Ewa. 2014. The social-ecological resilience of an eastern urbansuburban watershed: the Anacostia River Basin. Idaho Law Review 51:29-90.

Benson, M. H., D. Llewellyn, R. Morrison, and M. Stone. 2014. Water governance challenges in New Mexico's Middle Rio Grande Valley: a resilience assessment. Idaho Law Review 51:195-228. http://dx.doi.org/10.2139/ssrn.2464387

Birge, H., C. R. Allen, R. K. Craig, A. S. Garmestani, J. A. Hamm, C. Babbitt, K. Nemec, and E. Schlager. 2014. Social-ecological resilience and law in the Platte River Basin Platte River. Idaho Law Review 51:229-256.

Cech, T.V. 2003. Principles of water resources: history, development, management, and policy. John Wiley and Sons, Hoboken, New Jersey, USA.

Chaffin, B. C. 2014. Reallocating resources, rebuilding community: the Klamath Basin agreements and the emergence of adaptive governance. Dissertation. Oregon State University, Corvallis, Oregon, USA.
Chaffin, B., R. K. Craig, and H. Gosnell. 2014b. Resilience, adaptation, and transformation in the Klamath River Basin social-ecological system. Idaho Law Review 51:157-193.

Chaffin, B. C., H. Gosnell, and B. A. Cosens. 2014a. A decade of adaptive governance scholarship: synthesis and future directions. Ecology and Society 19(3):56. http://dx.doi.org/10.5751/ ES-06824-190356

Chaffin, B. C., and L. H. Gunderson. 2016. Emergence, institutionalization and renewal: rhythms of adaptive governance in complex social-ecological systems. Journal of Environmental Management 165:81-87. http://dx.doi.org/10.1016/j.jenvman.2015.09.003

Cosens, B. 2015. Application of the adaptive water governance project to the management of the Lake Eyre Basin and it connections to the Great Artesian Basin. Report to the Goyder Institute, Adelaide, South Australia. [online] URL: http://www. goyderinstitute.org/uploads/FU\%20LEB \%20GAP\%20Report-WEB. pdf

Cosens, B. A., R. K. Craig, S. Hirsch, C. A. (T.) Arnold, M. H. Benson, D. A. DeCaro, A. S. Garmestani, H. Gosnell, J. Ruhl, and E. Schlager. 2017. The role of law in adaptive governance. Ecology and Society 22(1):30. http://dx.doi.org/10.5751/ es-08731-220130

Cosens, B., and A. Fremier. 2014. Assessing system resilience and ecosystem services in large river basins: a case study of the Columbia River Basin. Idaho Law Review 51:91-126.

Cosens, B. A., L. Gunderson, and B. C. Chaffin. 2014. The adaptive water governance project: assessing law, resilience and governance in regional socio-ecological water systems facing a changing climate. Introduction to NREL Edition of the Idaho Law Review. Idaho Law Review 51:1-27.

Dietz, T., E. Ostrom, and P. C. Stern. 2003. The struggle to govern the commons. Science 302:1907-1912. http://dx.doi.org/10.1126/ science. 1091015

Folke, C., S. Carpenter, B. Walker, M. Scheffer, T. Elmqvist, L. Gunderson, and C. S. Holling. 2004. Regime shifts, resilience, and biodiversity in ecosystem management. Annual Review of Ecology, Evolution, and Systematics 35:557-581. http://dx.doi. org/10.1146/annurev.ecolsys.35.021103.105711

Garmestani, A. S., and C. R. Allen. 2014. Social-ecological resilience and law. Columbia University Press, New York, New York, USA. http://dx.doi.org/10.7312/garm16058

Gunderson, L., A. Garmestani, K. W. Rizzardi, J. B. Ruhl, and A. Light. 2014. Escaping a rigidity trap: governance and adaptive capacity to climate change in the Everglades social ecological system. Idaho Law Review 51:127-156.

Gunderson, L. H., and C. S. Holling. 2002. Panarchy: understanding transformations in systems of humans and nature. Island Press, Washington, D.C., USA.

Gunderson, L., and S. S. Light. 2006. Adaptive management and adaptive governance in the Everglades ecosystem. Policy Sciences 39:323-334. http://dx.doi.org/10.1007/s11077-006-9027-2

Hela, I. 1952. Remarks on the climate of south Florida. Bulletin of Marine Science 2(2):438-447. 
Holling, C. S. 1978. Adaptive environmental assessment and management. Wiley and Sons, London, UK.

Holling, C. S. 2001. Understanding the complexity of economic, ecological, and social systems. Ecosystems (4):390-405. http://dx. doi.org/10.1007/s10021-001-0101-5

Holling, C. S., and G. K. Meffe. 1996. Command and control and the pathology of natural resource management. Conservation Biology 10:328-337. http://dx.doi.org/10.1046/j.1523-1739.1996.10020328.

$\underline{\mathrm{x}}$

Intergovernmental Panel on Climate Change. 2007. Appendix 1: Glossary $A-D$. Climate change 2007: Impacts, Adaptation and Vulnerability. Contribution of Working Group II to the Fourth Assessment Report. Cambridge University Press, Cambridge, UK. [online] URL: http://www.ipcc.ch/publications and data/ ar4/wg2/en/annexessglossary-a-d.html

Light, S. S., L. Gunderson, and C. S. Holling. 1995. The Everglades: evolution of management in a turbulent ecosystem. Pages 103-168 in L. H. Gunderson, C. S. Holling, S. S. Light, editors. Barriers and bridges to the renewal of ecosystems and institutions. Columbia University Press, New York, New York, USA.

Milly, P. C. D., J. Betancourt, M. Falkenmark, R. M. Hirsch, Z. W. Kundzewicz, D. P. Lettenmaier, and R. J. Stouffer. 2008. Stationarity is dead: whither water management? Science 319:573-574. http://dx.doi.org/10.1126/science.1151915

Mote, P. W., A. F. Hamlet, M. P. Clark, and D. P. Lettenmaier. 2005. Declining mountain snowpack in western North America. Bulletin of the American Meteorological Society 86:39-49. http:// dx.doi.org/10.1175/BAMS-86-1-39

Nemec, K. T., J. Chan, C. Hoffman, T. L. Spanbauer, J. A. Hamm, C. Allen, T. Hefley, D. Pan, and P. Shrestha. 2013. Assessing resilience in stressed watershed. Ecology and Society 19(1):34. http://dx.doi.org/10.5751/ES-06156-190134

Resilience Alliance. 2010. Assessing resilience in social-ecological systems: a workbook for practitioners. Version 2.0. [online] URL: http://www.resalliance.org/files/ResilienceAssessmentV2_2.pdf

Richter, B. D., and G. A. Thomas. 2007. Restoring environmental flows by modifying dam operations. Ecology and Society 12(1):12. http://dx.doi.org/10.5751/es-02014-120112 